\title{
Membraneless hydrogen peroxide fuel cell using Prussian Blue as cathode material $\uparrow$
}

\author{
Seyed Ali Mousavi Shaegh, $*^{a, b}$ Nam-Trung Nguyen, ${ }^{* a b}$ Seyyed Mohsen Mousavi Ehteshami, ${ }^{a, b}$ Siew Hwa \\ Chan $^{a, b}$
}

\author{
${ }_{5}$ Received (in $\left.X X X, X X X\right)$ Xth $X X X X X X X X X 20 X X$, Accepted Xth $X X X X X X X X X 20 X X$ \\ DOI: 10.1039/b000000x
}

This communication describes the exploitation of Prussian Blue, ferric ferrocyanide $\left(\mathrm{Fe}_{4}{ }^{\mathrm{III}}\left[\mathrm{Fe}^{\mathrm{II}}(\mathrm{CN})_{6}\right]_{3}\right)$ ), for cathode side in a single-chamber membraneless fuel cell running on ${ }_{10}$ hydrogen peroxide $\left(\mathrm{H}_{2} \mathrm{O}_{2}\right)$ as both fuel and oxidant. An opencircuit potential (OCP) of $0.6 \mathrm{~V}$ has been obtained, which could be the highest $\mathrm{OCP}$ with $\mathrm{H}_{2} \mathrm{O}_{2}$ ever reported. The maximum power density was $1.55 \mathrm{~mW} / \mathrm{cm}^{2}$ and showed a stable long-term operation in acidic media.

15 Environment-friendly technologies for energy supply, storage and conversion are the challenges of twenty first century and need long-term fundamental innovative research ${ }^{1,2}$. Ideally, such technologies must be able to convert plentiful energy-poor molecules into energy-rich molecules using renewable energies,

20 mainly sunlight, with highly active but cheap and abundant catalyst materials ${ }^{3}$.

Interestingly, hydrogen peroxide is a carbon-free energy carrier that can be used as both fuel and oxidant in a fuel cell engine. The whole fuel cell system would have advantages of a simple 25 design $^{4}, 5$. Hydrogen peroxide has high energy density and decomposes into water and oxygen ${ }^{6}$. This compound is fairly nontoxic, and can be easily transported in aqueous phase ${ }^{6}$. Electricity generated by a photovoltaic solar cell can be used for hydrogen peroxide production through electrocatalytic reduction 30 of oxygen in an acidic aqueous solution. ${ }^{5}$

In order to use hydrogen peroxide as both fuel and oxidant, hydrogen peroxide can be exploited in basic and acidic supporting electrolytes representing fuel (electron donor) and oxidant (electron acceptor), respectively. In such a basic/acidic

35 bipolar electrolytes configuration, fuel and oxidant should be kept separate in a membrane-based design $^{7}$ or in a microfluidic channel $^{8}$ where diffusive mixing is limited to a confined liquidliquid interface. Using $1 \mathrm{M} \mathrm{H}_{2} \mathrm{O}_{2}$ in a $6 \mathrm{M} \mathrm{KOH}$ solution as fuel and $2 \mathrm{M} \mathrm{H}_{2} \mathrm{O}_{2}$ in a $1.5 \mathrm{M} \mathrm{H}_{2} \mathrm{SO}_{4}$ solution with $\mathrm{Ni} / \mathrm{C}$ and $\mathrm{Pt} / \mathrm{C}$ as 40 catalysts at anode and cathode sides in a Nafion-membrane fuel cell, a power density of $3.75 \mathrm{~mW} / \mathrm{cm}^{2}$ at a cell potential of $0.55 \mathrm{~V}$ was achieved. ${ }^{7}$ In a microfluidic cell running on $0.75 \mathrm{M} \mathrm{H}_{2} \mathrm{O}_{2}$ with $\mathrm{NaOH} / \mathrm{H}_{2} \mathrm{SO}_{4}$ electrolytes at a flow rate of $24 \mu \mathrm{L} / \mathrm{s}$ using $\mathrm{Pt}$ electrodes, a maximum power density of $23 \mathrm{~mW} / \mathrm{cm}^{2}$ at cell 45 potential of $0.3 \mathrm{~V}$ was obtained ${ }^{8}$.

There are few standing issues for such alkaline/acidic bipolar electrolytes. First, there is a mismatch between the supporting electrolytes of the anolyte and the catholyte. Second, using noble metals such as platinum Pt is certainly efficient for the reduction
50 of $\mathrm{H}_{2} \mathrm{O}_{2}$ to water. But concurrently, they also facilitate the direct decomposition of $\mathrm{H}_{2} \mathrm{O}_{2}$ to oxygen ${ }^{7-9}$. In addition, the exothermic neutralization of $\mathrm{H}^{+}$and $\mathrm{OH}^{-}$may happen because of the diffusive mixing of the reactants resulting in a consequent electrolyte consumption ${ }^{10}$.

${ }_{55}$ To address the above mentioned issues, $\mathrm{H}_{2} \mathrm{O}_{2}$ cam be used in a one-compartment fuel cell with electrodes of different reactivity to oxidation and reduction of $\mathrm{H}_{2} \mathrm{O}_{2}$ given by ${ }^{5,11}$ :

$$
\begin{array}{ll}
\text { Anode: } \mathrm{H}_{2} \mathrm{O}_{2} \rightarrow \mathrm{O}_{2}+2 \mathrm{H}^{+}+2 \mathrm{e}^{-} & \mathrm{E}^{\circ}=0.68 \mathrm{~V} \\
\text { Cathode: } \mathrm{H}_{2} \mathrm{O}_{2}+2 \mathrm{H}^{+}+2 \mathrm{e}^{-} \rightarrow 2 \mathrm{H}_{2} \mathrm{O} & \mathrm{E}^{\circ}=1.77 \mathrm{~V} \\
\text { Total: } 2 \mathrm{H}_{2} \mathrm{O}_{2} \rightarrow 2 \mathrm{H}_{2} \mathrm{O}+\mathrm{O}_{2} &
\end{array}
$$

The theoretical electromotive force for the reactions is $1.09 \mathrm{~V}$ which is comparable to the theoretical open-circuit potential $(\mathrm{OCV})$ of a hydrogen-oxygen fuel cell $(1.23 \mathrm{~V})$ and a direct methanol fuel cell $(1.21 \mathrm{~V})$.

${ }_{65}$ Yamazaki et al. ${ }^{4}$ developed an alkaline one-compartment fuel cell with a maximum open-circuit potential of $0.13 \mathrm{~V}$ using $\mathrm{Pt}, \mathrm{Pd}, \mathrm{Ni}$ and $\mathrm{Au}$ wires as selective anode and $\mathrm{Ag}$ wire as selective cathode. Yamada et al. $^{5}$ improved the OCV of an alkaline fuel cell to $0.16 \mathrm{~V}$ using Ag-Pb alloy nanoparticles as cathode with higher 70 surface area and improved reactivity due to the combination with an $\mathrm{Au}$ anode.

In a recent work, Yamada et al. ${ }^{11}$ developed an acidic onecompartment fuel cell using an iron phthalocyanine complex as cathode and $\mathrm{Ni}$ mesh as anode. Using $[\mathrm{FeIII}(\mathrm{Pc}) \mathrm{Cl}]$ as a cathode 75 material in an acetate buffer containing $300 \mathrm{mM} \mathrm{H}_{2} \mathrm{O}_{2}$ with $\mathrm{pH}$ of 3 , an OCV of $0.5 \mathrm{~V}$ with a maximum power density of $10 \mu \mathrm{W} / \mathrm{cm}^{2}$ and a limiting current density of $210 \mu \mathrm{A} / \mathrm{cm}^{2}$ were achieved. Since $\mathrm{H}_{2} \mathrm{O}_{2}$ is produced under acidic environment via the two-electron reduction of $\mathrm{O}_{2}$ using solar power ${ }^{5}$, operation 80 under acidic conditions is highly desirable in order to establish a hydrogen peroxide-based energy production and storage.

In this communication, we report a one-compartment fuel cell running on $\mathrm{H}_{2} \mathrm{O}_{2}$ as both fuel and oxidant under acidic conditions. Prussian Blue coated on carbon-fiber-based paper was used at the 85 cathode side while anode was made of silver foil (Ag) or nickel mesh (Ni), Figure 1. Prussian Blue or ferric ferrocyanide $\left(\mathrm{Fe}_{4}{ }^{\mathrm{III}}\left[\mathrm{Fe}{ }^{\mathrm{II}}(\mathrm{CN})_{6}\right]_{3}\right)$ is widely available and very cost effective compared to precious metals. ${ }^{12}$ Prussian Blue $(\mathrm{PB})$ is a renowned 
catalyst for $\mathrm{H}_{2} \mathrm{O}_{2}$ reduction under acidic conditions and its electrocatalytic reduction of hydrogen peroxide for biosensing and analytical applications has been studied extensively ${ }^{12,13}$.

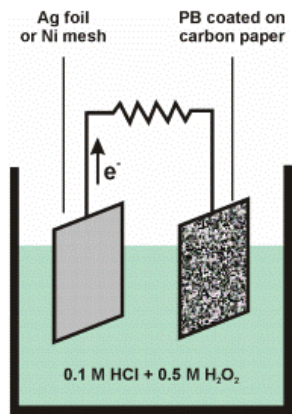

Fig. 1. A schematic figure of one-compartment fuel cell running on $\mathrm{H}_{2} \mathrm{O}_{2}$ as both fuel and oxidant. Supporting electrolyte is $0.1 \mathrm{M} \mathrm{HCl}$ dissolved in $0.5 \mathrm{M} \mathrm{H}_{2} \mathrm{O}_{2}$. The anode consists of either a silver foil or a nickel mesh. The cathode is made of Prussian Blue coated on carbon paper.

The procedure of chemical preparation of $\mathrm{PB}$ was adopted from elsewhere. ${ }^{9}$ Briefly, PB was synthesized chemically by mixing of $0.5 \mathrm{M} \mathrm{FeCl}_{3}$ in $0.1 \mathrm{M} \mathrm{HCl}$ with a solution of $\mathrm{K}_{3}\left[\mathrm{Fe}(\mathrm{CN})_{6}\right]$ in $0.1 \mathrm{M} \mathrm{HCl}$ at room temperature. To make $\mathrm{PB}$ supported on 10 carbon, the required amount of Vulcan XC-72 was suspended in $0.1 \mathrm{M} \mathrm{HCl} . \mathrm{K}_{3}\left[\mathrm{Fe}(\mathrm{CN})_{6}\right]$ in $0.1 \mathrm{M} \mathrm{HCl}$ and $0.5 \mathrm{M} \mathrm{FeCl}_{3}$ in $0.1 \mathrm{M}$ $\mathrm{HCl}$ were then added drop wise to the carbon slurry, respectively (Please refer to $\mathrm{ESI}^{\dagger}$ for catalyst preparation, characterization and electrode fabrication). Both unsupported and carbon-supported 15 synthesized PB were analyzed using powder X-ray diffraction (XRD) technique. Figure 2 shows pronounced peaks at $2 \theta=17.4$, $2 \theta=24.6,2 \theta=35.2$ and $2 \theta=39.4$ corresponding to $\mathrm{Fe}_{4}\left[\mathrm{Fe}(\mathrm{CN})_{6}\right]_{3}$. $\mathrm{xH}_{2} \mathrm{O}^{9}$. The XRD peaks for both carbon-supported and unsupported $\mathrm{PB}$ remained identical indicating that the 20 modification process has no effect on the crystallinity of PB. There was also no reaction between PB and carbon.

The electrocatalytic reduction of $\mathrm{H}_{2} \mathrm{O}_{2}$ over $\mathrm{PB}$ was examined in a three-electrode cell with a rotating ring-disk glassy carbon electrode. Small portions of unsupported and carbon-supported ${ }_{25}$ PB solution containing Nafion $(2 \mu \mathrm{l})$ were placed on the glassy carbon electrode. Figure 3 shows the cyclic voltammetry (CV) results of $\mathrm{H}_{2} \mathrm{O}_{2}$ on a glassy carbon electrode modified by unsupported $\mathrm{PB}$ in a supporting electrolyte of $0.1 \mathrm{M} \mathrm{HCl}(\mathrm{pH}=1)$ containing $0.5 \mathrm{M} \mathrm{H}_{2} \mathrm{O}_{2}$. It is worth mentioning that many large 30 fluctuations and asperities were observed while conducting cyclic voltammetry of the carbon-supported $\mathrm{PB}$ in the presence of $\mathrm{H}_{2} \mathrm{O}_{2}$, which are likely due to the limitation of $\mathrm{H}_{2} \mathrm{O}_{2}$ transport to the electrode. Rapid emergence of bubbles, even at high rotating speed of $2500 \mathrm{rpm}$, was observed over the glassy carbon 35 modified by carbon-supported PB. Since the cathodic reaction (2) does not liberate any gases, bubble generation is associated with $\mathrm{H}_{2} \mathrm{O}_{2}$ decomposition reaction.

Cyclic voltammogram of the unsupported $\mathrm{PB}$ in the $0.5 \mathrm{M} \mathrm{HCl}$ solution in the absence of $\mathrm{H}_{2} \mathrm{O}_{2}$ indicates that there is no specific 40 catalytic current of $\mathrm{H}_{2} \mathrm{O}_{2}$ reduction in the cathodic sweep.

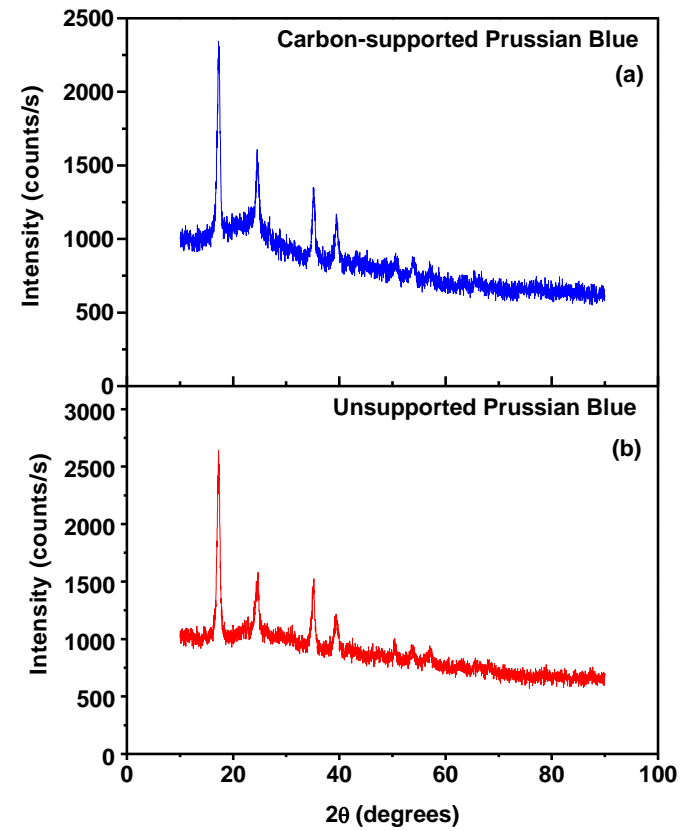

Fig. 2. Powder X-ray diffraction (XRD) patterns for carbon-supported and (b) unsupported Prussian Blue.

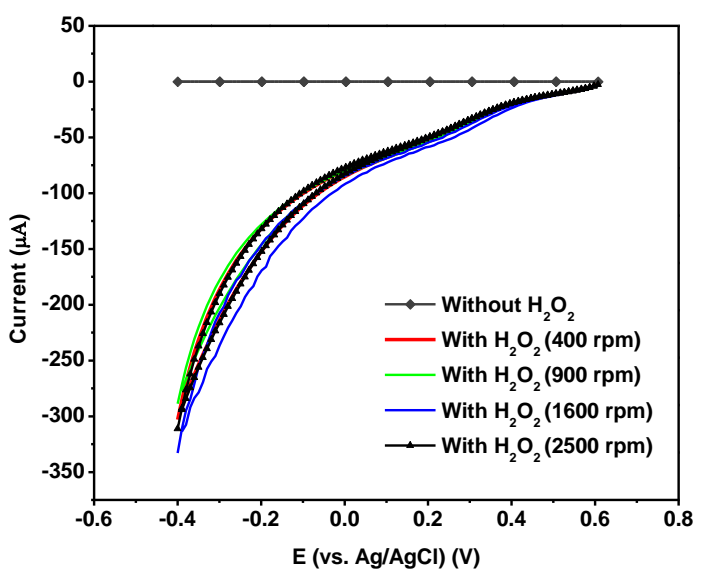

Fig. 3. Cyclic voltammograms of $\mathrm{H}_{2} \mathrm{O}_{2}$ on glassy carbon electrode modified by unsupported $\mathrm{PB}$. The measurements were performed in an aqueous electrolyte of $0.1 \mathrm{M} \mathrm{HCl}$ containing $0.5 \mathrm{M} \mathrm{H}_{2} \mathrm{O}_{2}$. Scan rate of $10 \mathrm{mVs}^{-1}$ was selected.

As shown in Figure 3, cyclic voltammograms of the unsupported $\mathrm{PB}$ in the presence of $\mathrm{H}_{2} \mathrm{O}_{2}$ show the onset potential for $\mathrm{H}_{2} \mathrm{O}_{2}$ reduction on the glassy carbon electrode with $\mathrm{PB}$ is $0.6 \mathrm{~V}$. In 45 order to have selective electrodes, the onset potential for $\mathrm{H}_{2} \mathrm{O}_{2}$ oxidation on an electrode of interest should be lower than the onset potential for $\mathrm{H}_{2} \mathrm{O}_{2}$ reduction over $\mathrm{PB}$. As a case study, the onset potential for $\mathrm{H}_{2} \mathrm{O}_{2}$ oxidation on a nickel (Ni) electrode and on a silver $(\mathrm{Ag})$ electrode in alkaline medium are $c a .-0.09 \mathrm{~V}$ and $50 \mathrm{ca}$. $-0.11 \mathrm{~V}^{4}$, respectively. Both potentials are lower than $0.6 \mathrm{~V}$. Therefore, $\mathrm{Ni}$ and $\mathrm{Ag}$ electrodes were selected as potential anodes for the fuel cell. Since PB is not stable in alkaline conditions, the selectivity of $\mathrm{Ni}$ and $\mathrm{Ag}$ electrodes compared to $\mathrm{PB}$ were 
examined in a fuel cell with acidic medium.

PB-coated electrodes were prepared by spraying a solution of PB containing Nafion ${ }^{\circledR}$ on a piece of carbon paper. Silver anode was made of a thin silver plate from Sigma-Aldrich while nickel 5 anode was a metallic mesh. Anode and cathode were immersed in a solution of $0.5 \mathrm{M} \mathrm{H}_{2} \mathrm{O}_{2}$ with a supporting electrolyte of $0.1 \mathrm{M}$ $\mathrm{HCl}$.

Linear potential sweep voltammetry was carried out to examine 10 the potential-current characteristics of the single-compartment fuel cell. Figure 4 shows that the fuel cell has a high open circuit potential of $0.53 \mathrm{~V}$ and $0.6 \mathrm{~V}$ using silver and nickel anode, respectively. In addition, a maximum power density of $c a$. $0.8 \mathrm{~mW} / \mathrm{cm}^{2}$ at $0.3 \mathrm{~V}$ with a silver anode and a maximum power 15 density of $c a .1 .55 \mathrm{~mW} / \mathrm{cm}^{2}$ at $0.3 \mathrm{~V}$ with a nickel anode were observed. These results are two orders of magnitude higher than the best results reported in the literature, which was $10 \mu \mathrm{W} / \mathrm{cm}^{2}$ 11. In addition, the PB coated on carbon paper was very stable under acidic condition. This condition is compatible with the 20 production of $\mathrm{H}_{2} \mathrm{O}_{2}$ through the electrochemical two-electron reduction of $\mathrm{O}_{2}{ }^{5}$.

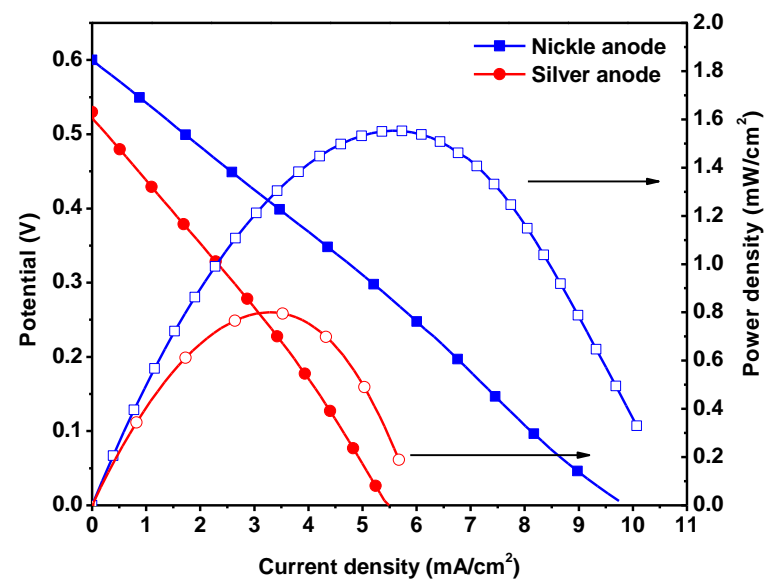

Fig. 4. Current-potential and current-power curves of the singlecompartment $\mathrm{H}_{2} \mathrm{O}_{2}$ fuel cell with nickel and silver anodes and 25 unsupported PB coated on carbon paper as cathode. Performance tests were carried out under acidic condition using $0.1 \mathrm{M} \mathrm{HCl}$ and $0.5 \mathrm{M} \mathrm{H}_{2} \mathrm{O}_{2}$.

\section{Conclusions}

A high performance membraneless $\mathrm{H}_{2} \mathrm{O}_{2}$ fuel cell using Prussian Blue as cathode and silver and nickel as anode materials in an 30 acidic medium was realized. Open-circuit potential and maximum power density is improved significantly compared to the past results reported in the literature. The current design provides a strong platform for further developments. Prussian Blue is highly stable in acidic environment with high electroactivity towards the 35 reduction of $\mathrm{H}_{2} \mathrm{O}_{2}$, consequently other materials can be explored for lower anode overpotential (see ESI $\uparrow$ ). Since carbon-supported Prussian Blue facilitated the spontaneous decomposition of $\mathrm{H}_{2} \mathrm{O}_{2}$, other support materials should be explored in the future.

In addition, the current fuel cell design is very suitable for on40 chip power generation schemes such as powering portable lab-onchip devices ${ }^{14}$ and off-the grid micro sensors ${ }^{15}$, 16 . Fuel crossover and mixing of fuel and oxidant is not an issue for this concept. Unlike microfluidic fuel cells, continuous streams of fuel and oxidant are not required to keep fuel separated from oxidant ${ }^{17}$. ${ }_{45}$ Compared to other on-chip power sources ${ }^{14-16}$, the fuel cell reported here has a simple design without a membrane electrode assembly (MEA), a superior performance and easy fuel/oxidant handling. These features allow the fuel cell to be integrated with other microdevices for portable applications.

\section{${ }_{50}$ Acknowledgments}

The authors would like to thank Assistant Professor Chee-Seng Toh and Lai Peng Wong from School of Physical and Mathematical Sciences, Nanyang Technological University for their valuable comments.

\section{${ }_{55}$ Notes and references}

a School of Mechanical and Aerospace Engineering, Nanyang Technological University, 50 Nanyang Аvenue, Singapore 639798, Singapore, Tel:(0065) 6790-445, Fax:(0065)6791-1859 (Nam-Trung Nguyen), Email: seye0003@ntu.edu.sg (Seyed Ali Mousavi Shaegh), 60 Email: mntnguyen@ntu.edu.sg (Nam-Trung Nguyen).

${ }^{b}$ Energy Research Institute at NTU (ERI@N), Singapore 637553, Singapore.

$\uparrow$ Electronic Supplementary Information (ESI) available: [details of any supplementary information available should be included here]. See 65 DOI: 10.1039/b000000x/

1. G. M. Whitesides and G. W. Crabtree, SCIENCE, 2007, 315, 796798.

2. P. Poizot and F. Dolhem, Energy Environ. Sci., 2011, 4, 2003-2019.

70 3. H. B. Gray, Nat Chem, 2009, 1, 7-7.

4. S.-i. Yamazaki, Z. Siroma, H. Senoh, T. Ioroi, N. Fujiwara and K. Yasuda, Journal of Power Sources, 2008, 178, 20-25.

5. Y. Yamada, Y. Fukunishi, S.-i. Yamazaki and S. Fukuzumi, Chemical Communications, 2010, 46, 7334-7336.

75 6. R. S. Disselkamp, International Journal of Hydrogen Energy, 2010, 35, 1049-1053.

7. A. E. Sanli and A. Aytac, International Journal of Hydrogen Energy, 2011, 36, 869-875.

8. S. Hasegawa, Shimotani, K., Kishi, K., Watanabe, H., 80 Electrochemical and Solid-State Letters, 2005, 8, A119-A121.

9. G. Selvarani, S. K. Prashant, A. K. Sahu, P. Sridhar, S. Pitchumani and A. K. Shukla, Journal of Power Sources, 2008, 178, 86-91.

10. E. R. Choban, Spendelow, J. S., Gancs, L., Wieckowski, A., Kenis, P. J. A., Electrochimica Acta, 2005, 50, 5390-5398.

85 11. Y. Yamada, S. Yoshida, T. Honda and S. Fukuzumi, Energy Environ. Sci., 2011, 4, 2822-2825.

12. A. A. Karyakin, Electroanalysis, 2001, 13, 813-819.

13. F. Ricci and G. Palleschi, Biosensors and Bioelectronics, 2005, 21, 389-407.

90 14. J. P. Esquivel, M. Castellarnau, T. Senn, B. Lochel, J. Samitier and N. Sabate, Lab on a chip, 2011.

15. S. Tominaka, Ohta, S., Obata, H.Momma, T., Osaka, T., Journal of the American Chemical Society, 2008, 130, 10456-10457.

16. S. Tominaka, H. Nishizeko, S. Ohta and T. Osaka, Energy Environ. Sci., 2009, 2, 849-852

17. S. A. Mousavi Shaegh, Nguyen, N.T., Chan, S.H., International Journal of Hydrogen Energy, 2011, 36, 5675-5694. 